Dancing with Knives: American Cold War Ideology in the Dances of West Side Story

Author(s): Daniel Belgrad, Ying Zhu

Source: Kyiv-Mohyla Humanities Journal 3 (2016): 1-22

Published by: National University of Kyiv-Mohyla Academy

http://kmhj.ukma.edu.ua/ 


\title{
Dancing with Knives: American Cold War Ideology in the Dances of West Side Story
}

\author{
Daniel Belgrad \\ University of South Florida, \\ Department of Humanities and Cultural Studies
}

\section{Ying Zhu}

University of South Florida,

School of Theatre and Dance

\begin{abstract}
In cultural studies today, there is emerging an interpretive revolution "from below" — that is, a radical reassessment of the politics of cultural forms, based on a recovery of the embodied and affective subject as the center of meaning-making. Making sense of dance performances is therefore methodologically important because of their particular ability to offer insight into these two aspects of subjectivity. As an artifact of Cold War American culture, Jerome Robbins' choreography in the film West Side Story (1961) enforces an ideological distinction between legitimate and illegitimate forms of violence, through its portrayals of "cool" affect as a necessary disposition, and organized violence as a necessary evil. Our close analysis of the dances "Rumble" and "Cool" offers new insights into the affective "map" that provided the ideological foundation for American political theorists and policy makers in formulating their Cold War attitudes.
\end{abstract}

Key Words: dance studies, affect, militarism, Jerome Robbins, choreography, ideology.

\section{(2)}

West Side Story, a dance musical conceived and choreographed by Jerome Robbins, is a classic of American musical theater. The original Broadway production premiered in 1957. The 1961 film version garnered eleven Academy Award nominations and won ten of them, including Best Picture. During this same span of years, there occurred some of the most heated moments of Cold War confrontation between the United States and the Soviet Union, including brinksmanship by both sides in the deployment of nuclear-armed missiles; the promulgation of the Eisenhower Doctrine; the 14 July Revolution in Iraq; the Cuban revolution and the Bay of Pigs invasion; the building of the Berlin Wall; and the beginning of the war in Vietnam. This essay argues that the constructions of gang violence in the film West Side Story participated in the ideological work of American Cold War political culture, supporting its militaristic aspects.

Any connection between events in such different spheres of cultural activity asinternational politics and Broadway theater can only be traced by an investigation into ideological processes. As the renowned postcolonial theorist Gayatri Spivak has written: 
The relationship between global capitalism (exploitation in economics) and nationstate alliances (domination in geopolitics) is so macrological that it cannot account for the micrological texture of power. To move toward such an accounting one must move toward theories of ideology — of subject formations that micrologically and often erratically operate the interests that congeal the macrologies. ${ }^{1}$

Ideology, as Antonio Gramsci defined it, is the "spontaneous philosophy" of everyday life. By this he meant the unspoken but omnipresent beliefs and distinctions by which individual subjects map their life experiences to meaning, thereby legitimating some social relations and behaviors while rejecting others. ${ }^{2}$ Ideological beliefs are often not consciously held or articulated. Instead they manifest themselves "symptomatically" in behaviors - including rhetorical structures - that emerge from both conscious and unconscious decision-making processes. $^{3}$

West Side Story retells the Shakespearean tragedy of Romeo and Juliet, resituating it in a contemporary setting. Its ill-fated romance between Tony and Maria develops in the context of a gang war waged between two groups of urban teens: the white-immigrant Jets and the PuertoRican Sharks. Scholarly critics who have analyzed the film's social implications have typically focused on the ethnic dimension of this rivalry, reading the film as either a defense of ethnic pluralism or a reinscription of white privilege. ${ }^{4}$ But a close attention to the musical's dances as opposed to its plot illuminates a different social angle: one that establishes its ideological role in relation to American Cold War militarism.

The crisis in the movie's plot occurs during a "rumble" between the Jets and the Sharks. As the film makes clear, the two gangs are playing at war. They have held a ritualistic "war council" in which the rumble's parameters - the time, place, and method of battle - have been agreed upon. In the scene immediately preceding the rumble, we see them as they gather themselves and their weapons, singing and dancing to prepare themselves psychologically for the battle ahead. Unexpectedly, the rumble, which was planned to be a fistfight between two chosen champions, deteriorates into a knife fight in which Tony kills Maria's brother Bernardo. This unwanted escalation in the level of violence between the two gangs comes in an unpremeditated, emotionally charged moment that punctuates the more extended process of regulated violence and threats of violence that characterized their previous relationship.

By closely examining this rumble scene and the subsequent dance number (named "Cool") in a cultural context, we can discern the ideological uses of a popular dance musical focused on playing war. In doing so, we hope to achieve two intersecting purposes. The first is to gain an improved understanding of how Americans of that period perceived Cold War violence and

Gayatri Spivak, "Can the Subaltern Speak?" in Marxism and the Interpretation of Culture, ed. C. Nelson et al. (Basingstoke: Macmillan Education, 1988), 274.

3 See Fredric Jameson, The Political Unconscious (Ithaca: Cornell University Press, 1982), 34, 39, and 44.

4 See for example Frances Negrón-Muntaner, "Feeling Pretty: West Side Story and Puerto Rican Identity Discourses," Social Text 18.2 (2000): 83-106; and Alberto Sandoval-Sanchez, José Can You See: Latinos On and Off Broadway (Madison: University of Wisconsin Press, 1993). 
their relationship to it. The second is to demonstrate the methodological usefulness of affect theory and dance studies to the field of cultural studies in general.

\section{Ideology, Affect, and Dance Studies}

Ideology, because it is not primarily conscious or rational, inheres in what Marxist theorist Raymond Williams called "structure[s] of feeling." Ideology must therefore be understood to engage affective strategies in its processes of subject formation. Affect is the physiological "feeling" response of the human organism to experience. Emotions, or what psychologist Silvan Tomkins called "affective complexes," are affects as they are structured cognitively and culturally (that is, named, for example, as "fear" or "excitement," and linked with associations and value judgments). ${ }^{6}$ Ideology can be understood to be reproduced through the creation of affective complexes in the subject, and via the social reinforcement of behaviors that are deemed appropriate responses to those affective complexes. In this light, ideology can be usefully reconceptualized as a system of self-reinforcing feedback loops between the social order, individual behaviors, and affective experiences; together these constitute a constructed "reality."

In her book Dancing on the Canon, Sherril Dodds traces the genealogy of cultural studies and identifies the field's attendance to (popular) culture as an important site through which "complex power relations are played out." 7 In so doing, she also exposes the relative dearth of embodied artifacts examined within this discipline and thus advocates for attention to the body's scripts as sources through which social identities are composed and unsettled. Even in cultural studies, which invites into its field of vision a broad spectrum of materials for investigation, "there is never sufficient investment in how the dancing body articulates these complex social values and exchanges as movement description is very rarely addressed." 8 However, there is underway in cultural studies today a radical reassessment of the politics of many cultural texts and practices, based on a recovery of the embodied and affective subject as the center of meaning-making. Making sense of dance is methodologically important in this respect, because of dance's particular ability as a communicative medium to offer insights into the affective and embodied aspects of subjectivity. ${ }^{9}$

Dance Studies emerged as a formally delineated field of study in the late twentieth century, emphasizing research addressing the body as a medium for representation. In 1986, Susan Foster's Reading Dancing: Bodies and Subjects in Contemporary American Dance proposed

5 Raymond Williams, The Long Revolution (NY: Columbia University Press, 1961), 48-71.

6 Charles Altieri, The Particulars of Rapture: An Aesthetics of the Affects (Ithaca: Cornell University Press, 2003), 39 and 43-44. Silvan Tomkins, Exploring Affect: The Selected Writings of Silvan S. Tomkins, ed. E. Virginia Demos (New York: Cambridge University Press, 1995), 43-44 and 59. Sherril Dodds, Dancing on the Canon: Embodiments of Value in Popular Dance (New York: Palgrave Macmillan, 2011), 43 .

8 Dodds, Dancing on the Canon, 44.

9 Derek McCormack, Refrains for Moving Bodies: Experience and Experiment in Affective Spaces (Durham: Duke University Press, 2014), 2. 
an epistemological conception of the dancing body as a site of cultural production. Her project devises a methodology for analyzing dances and evidencing the meaning-making capacity of the body. There followed seminal interventions from a now-eminent cohort of dance scholars. ${ }^{10}$ Whereas traditionally, humanistic and social-science scholars often perceive the body as a passive entity upon which ideas are imposed or "inscribed" - the body as something upon which to write - Dance Studies takes dancing bodies as instruments of writing, and investigates bodily articulations as essential to how we frame, understand, and decipher meaning. Most recently, the field has seen an explosion of the conventional notions of "dance" and "choreography," broadening these terms to include all moves and postures that constitute deliberately designed actions. ${ }^{11}$ In this light, contemporary Dance Studies entails an interpretive scrutiny of bodily motions and comportments akin to the detailed analysis of word choice and narrative structure that is typically undertaken in the "close reading" of literary texts.

Paying deliberate attention to the placement of bodies in space, their movements through space, and the affective qualities of both, this essay explores the relationship between violence and affect that is represented in the film West Side Story. As a result we can grasp how the film reinforced two basic assumptions of America's Cold War militarization. The first is the conviction that violent confrontation is a necessary evil. The second, the belief that "good" violence can be distinguished from "bad" violence by its affective qualities.

\section{Rumble ‘em Right}

When the two gangs stage their "rumble" under the highway, the potential exists to avoid unwanted violence by adhering to a choreography previously decided on in the "war council." It is to be a fistfight between two champions, one from each side. If the rumble had gone as planned, it would have remained safely within the category of bodily and affective interactions that we can call "brawling." Brawling is introduced in the first scene of the movie, as the gangs chase each other through the streets of the city and the Sharks bait the Jets into several physical ambushes, dumping yellow paint on their heads, shoving them out of entryways, and pelting them with garbage. The stakes of brawling are bruised reputations, possible contusions, and dirtied shirts; in other words, the stakes of brawling are not lethal. There is a level of violent confrontation present, but the movie integrates it with other movements that clearly belong within a vocabulary of play, marking brawling as a form of competitive play. For example, the Jets repeatedly execute a leaping twirl with their right arms extended over their heads; and the two gangs play leapfrog at the entrance to a covered brick alleyway. Similarly, when they initially

10 Members of this early population of dance scholars include Brenda Dixon Gottschild, Jane

C. Desmond, Susan Manning, and Mark Franko - some of whom are cited in this essay. See also,

Jane C. Desmond, “Embodying Difference: Issues in Dance and Cultural Studies," Cultural Critique 26 (1993-1994): 33-63; Susan Manning, Ecstasy and the Demon: Feminism and Nationalism in the Dances of Mary Wigman (Berkeley: University of California Press, 1993); Mark Franko, Dance as Text: Ideologies of the Baroque Body (Cambridge: University Press, 1993).

11 See, for example, David Gere, How to Make Dances in an Epidemic: Tracking Choreography in the Age of AIDS (Madison: University of Wisconsin Press, 2004), 9. 
face off at the beginning of the rumble, Ice and Bernardo, the two champions, circle each other warily, using trained boxing techniques. Their clenched fists are aimed sharply at each other, but though they are creating a spectacle of violence for onlookers from both sides, the damage they are likely to inflict is minimal.

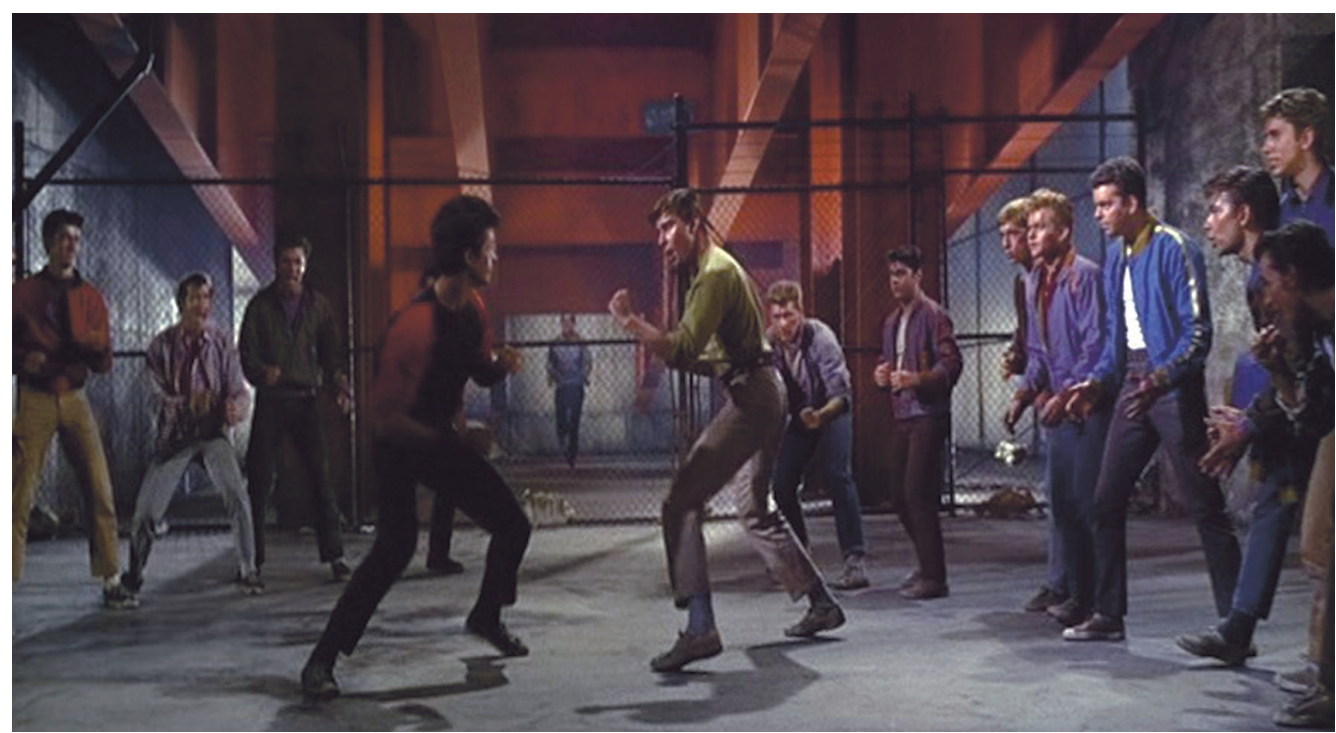

"Fair fight."12

It is only when Tony persists in interrupting the agreed-upon choreography that excessive violence ensues. He scales the chain link fence that delineates the fight area, yelling, "Hold it!" Riff, the leader of the Jets gang, misunderstanding Tony's intentions and believing that he has come in support of the Jets, runs to welcome him and, gesturing with his hands toward the place where the other Jets are lined as spectators, tells him, "Get with the gang; it's all OK." Ice then makes a similar inviting gesture to Bernardo, welcoming him to continue their fistfight in the wake of this minor interruption. The similarity between the gestures of Riff and Ice invokes the social nature of a violence that is conducted according to "rules of warfare." But Tony, instead of joining the other Jets on the sidelines, proceeds to intervene between the combatants, lunging at Ice's torso and shoving him to the side of the "boxing ring" in mid-swing. Riff asks, bewildered, "Tony, what are you doing?"

Tony intends to talk the two gangs out of their conflict. He has sentimentally promised Maria that there will be no violence, not even a fistfight. But the movie shows emphatically that this will not work. When Tony offers an outstretched hand to Bernardo in repeated attempts to affirm a truce, Bernardo responds by shoving him with such force that Tony stumbles to the ground. Riff then jumps into the ring like a boxing referee (feet planted wide apart, and arms extended, one hand gesturing towards Bernardo and the other facing Ice) to try to re-establish the choreographed nature of the combat.13 "Now let's just cool it — the deal is a fair fight between Home Entertainment, 1998). Unless otherwise noted, all subsequent images are from this source. 
you and Ice," he reminds Bernardo. Grabbing the sleeve of Tony's jacket, he reiterates, "Come on, get with the gang." But Tony still persists in his efforts to preclude any violence whatsoever. His pacifism is met disparagingly by Bernardo, who taunts him with sharp slaps across the face and torso as he clucks at him to imply that he is "chicken" and derides him with accusations of being a "pretty boy."

Pushed and prodded, Tony for a moment reverts to habit and assumes a boxing stance. But then he relinquishes it, and emotions rise even further. The choreographed one-on-one form of the combat breaks down as the Sharks converge on him in a disorderly mass, taunting him. Attempting to repel their physical and verbal assaults, Tony backs away into the crowd of Jets and, in his highly emotional state seemingly unable to distinguish friends from enemies, starts screaming at Ice. The cinematography is at pains to represent the characters as confused and overwhelmed by their own emotions. Ice forcefully grasps Tony's shoulders, trying one last time to remove him as an impediment to the original choreography. But then Riff runs in and punches Bernardo on the jaw. Non-diegetic, discordant music wells up on the soundtrack as the two gang leaders simultaneously, with surprise and fear registering intensely on their faces, pull switchblades from their back pockets.

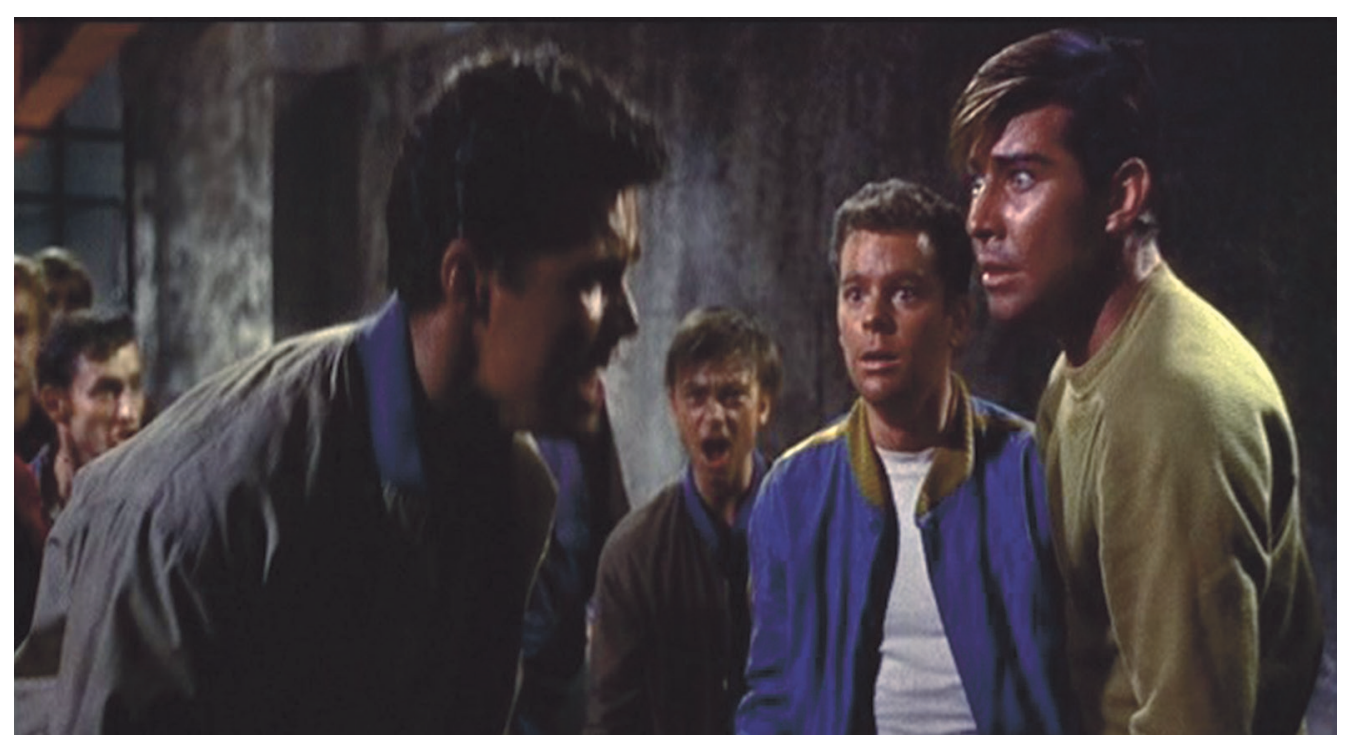

Overcome by emotions

Tony's disruption of the choreographed fighting has made the situation worse. ${ }^{14}$ Hoping to stop a fistfight, he has instigated a knife fight. But for this, too, there is thankfully a choreography, and Ice and Tiger hold Tony on the sidelines to prevent him from disrupting it. Riff and Bernardo circle each other, feinting and jabbing with their knives; but their actions, like the earlier boxing, do no realdamage. In blocking one of Riff's attempted attacks, Bernardo disarms him and drives him against the surrounding chain link fence. Splayed against the fence with his arms and legs spread-eagled, Riff nevertheless warns the others to "Keep outta this!" as both sides begin to swarm in. A moment of calm follows, in which the regulated nature of the

14 Of course, because this is a staged performance, all the actors' moves are choreographed; but what is important is the represented contrast between "choreographed" and "unchoreographed" fighting. 


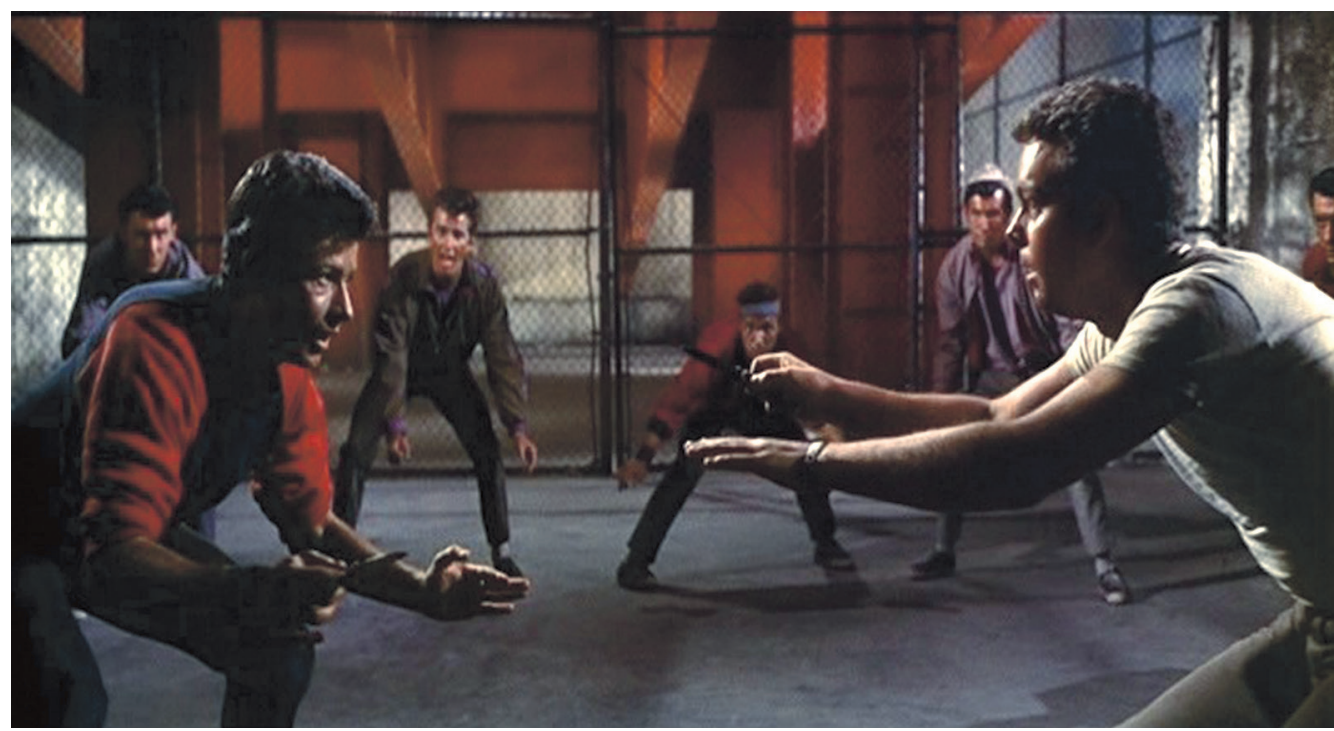

Choreographed fighting is restored

combat has been reaffirmed. The converging gang members back away, and Bernardo playfully taunts Riff by tossing his switchblade jauntily from hand to hand. Then Action rearms Riff with a new switchblade and the pas de deux continues.

However a short while later, Tony breaks free of his captors and interrupts the choreography again, this time fatally. He drags Riff away from the fight; and when Riff escapes and runs back to reengage the battle, he accidentally impales himself on Bernardo's blade. Tony then loses all emotional control and, yelling inarticulately, stabs Bernardo to death. This unchoreographed

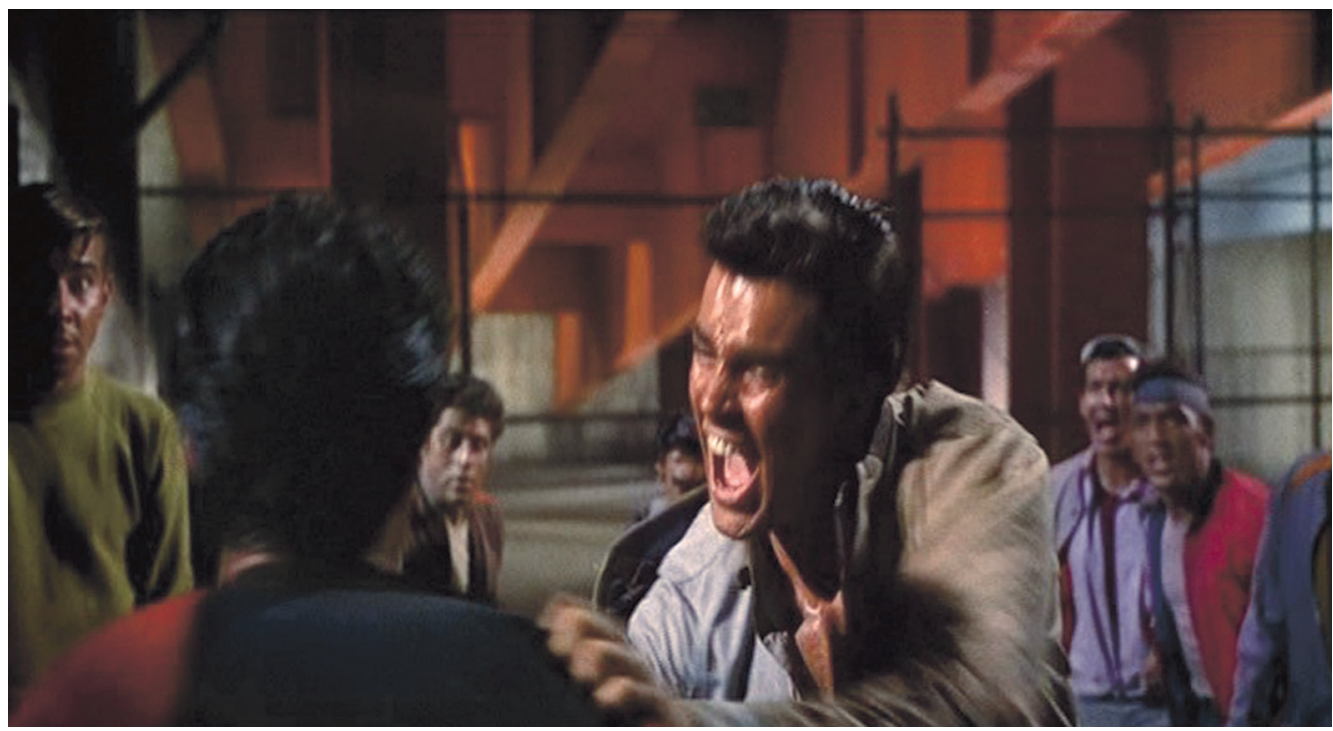

Tony loses his cool

violence then spreads everywhere, as all the other gang members lose their heads and the two gangs engage in a free-for-all battle. They only come back to their senses when the sound of approaching police sirens prompts them all to flee the scene. The camera films the riot from an oddly tilted low angle to heighten the impression of chaos. 


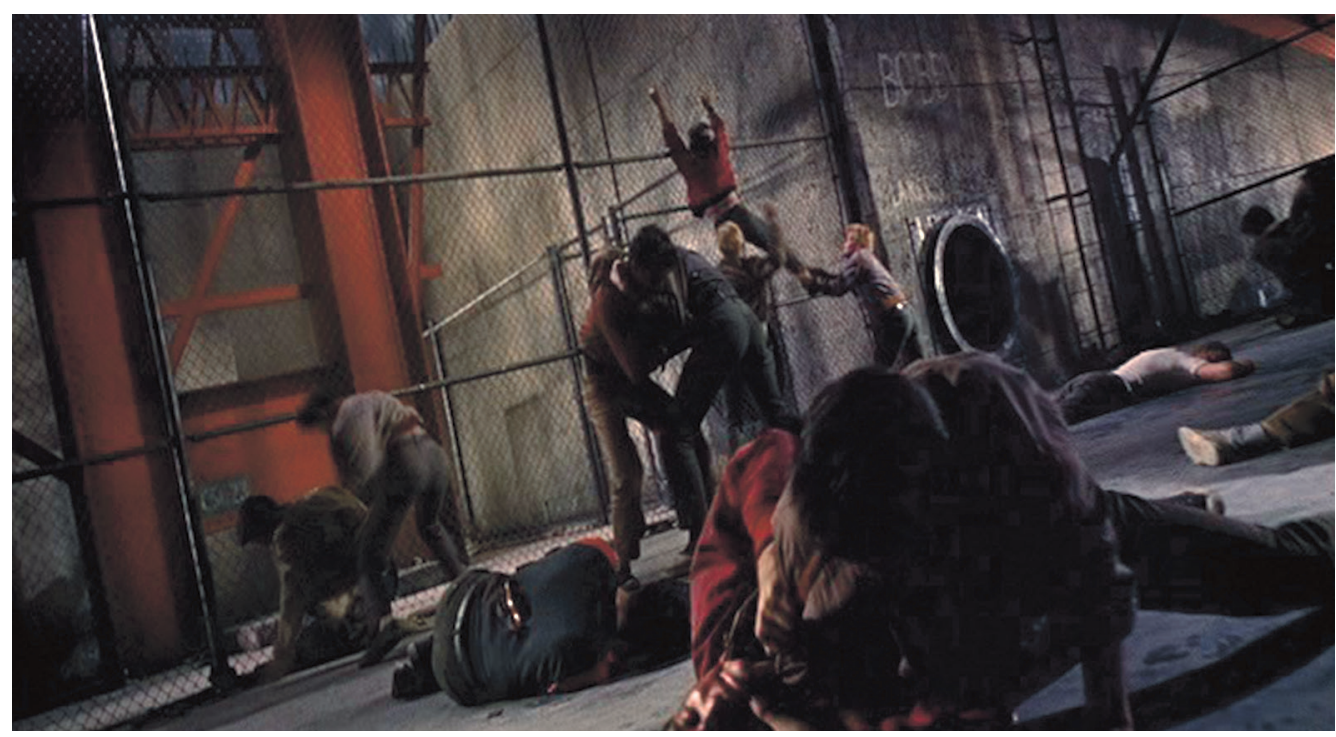

Chaos ensues

By committing the double sin of refusing to engage confrontationally and interrupting the choreography of conflict, Tony enables a catastrophic unleashing of emotionally charged violence. Thus the rumble scene presents and contrasts two types of violence: one characterized by planned confrontation and controlled emotions and marked as socially acceptable (even playful); and the other characterized by emotional frenzy and marked as pathological. The movie's contrast between "cool" or "relaxed" anger, which is marked as good for fighting, and uncontrolled anger, which is marked as dangerous, represents an important ideological distinction in American Cold War culture, creating a bifurcation between legitimate and illegitimate forms of violence. Whereas discursively it was asserted that a "cool" affect was good because it made good fighters, ideologically fighting became "good" by virtue of its being disciplined. Affective discipline legitimated the violence, in a Gramscian sense of that term, conferring "an aura of moral authority" that fostered public acquiescence to the exercise of military power. ${ }^{15}$

\section{Anger, Fighting, and Dancing}

American Army psychologists during and after the Second World War identified two excessive emotions - rage and fear - as the most detrimental to the combat enterprise. An article in the journal War Medicine in 1944 used schematic drawings to communicate this truth to the common soldier. ${ }^{16}$ These drawings show that in the normal psychological state, reason is in the driver's seat; body movements are regulated; and the emotions are restrained. But in the face of unknown dangers, reason and self-control may abandon their posts, and the emotions are unleashed.

15 Lears, "The Concept of Cultural Hegemony," 568-69.

16 Ellen Herman, The Romance of American Psychology: Political Culture in the Age of Experts (Berkeley:

University of California Press, 1996), 103-4, http://ark.cdlib.org/ark:/13०3o/ft696nb3n8/. 

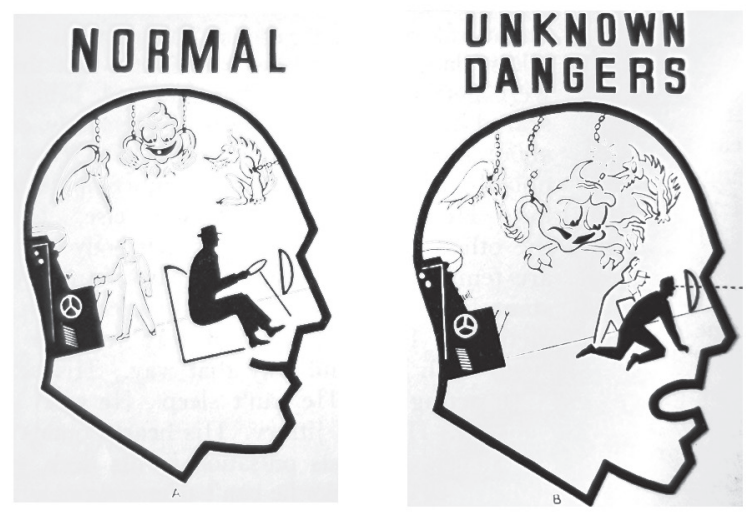

The effects of Unknown Dangers on self-control, from War Medicine (1944). ${ }^{17}$

In the military discourse concerning the ideal relations between fighting and affect, a psycho-physiological discipline was identified as the key factor for achieving the proper uses of violence. This was inculcated through military drills. Contrary to what is often assumed, military drills are not solely or even primarily aimed at building physical strength. Rather, preventing the fighter's emotions from overwhelming his fighting ability has historically been one of the main purposes of military training. Training Makes the Soldier, claims the title of a section in the 1943 manual Psychology for the Fighting Man. In it the author asserts that practice drills are all-important in bridging the psychological gap between a soldier's knowing what to do and his being able to do it under the emotional duress of actual battle conditions: "Habit formation is a further stage of learning. It depends on practice, experience, repetition [...] That is why drill is so important [...] Thoroughly drilled habits enable the soldier to act [...] even when his mind is confused and thinking is almost impossible."18

And military drills are, it is important to recognize, a kind of dance choreography. Fighting techniques are choreographic in that they dictate prescribed and proscribed bodily motions and positions. Combat training maps out a sequence of steps and body positions that must be learned and adhered to. Citing instructions for 17th- and 18th-century military drills and marches, Michel Foucault traces the military's meticulous manipulation and training of the

R. Robert Cohen, "Factors in Adjustment to Army Life: A Plan for Preventive Psychiatry by Mass Psychotherapy," War Medicine 5 (February 1944): 9 o.

18 Edwin Boring et al., Psychology for the Fighting Man (Washington, Infantry Journal: Penguin Books, 1943), 200 and 202. This discourse continues today, as evidenced by the online forum Defensive Carry in the thread, "How Helpful is Being Angry When In A Fight?": "You need to train for combat and practice fighting regularly if you want to be cool and in control of a physical engagement [...] because powerful, accurate and well-timed strikes require a kind of relaxation you can't achieve if you are emotionally swept up in the turmoil of harsh anger." Defensive Carry.com, accessed November 21, 2011, http://www.defensivecarry.com/forum/carry-defensive-scenarios/131675-how-helpful-beingangry-when-fight.html. 
body, whereby the specific angle of the head, the length and manner of a foot step, the location of an arm, and the posture of the torso are all carefully controlled. ${ }^{19}$

The alliance between dance and military training has a long historical trajectory. Royal court ceremonies that included both dance and military display were deployed during the Italian Renaissance to affirm ruling power. ${ }^{20}$ During Louis XIV's reign in France, there evolved a symbiotic relationship between balletic and military performance. Not only did portrayals of combat and military might figure prominently in formal ballets, but dance was decreed as a useful form of training for the armed nobility, since the coordination it inculcated was understood to enhance their performance in battle. ${ }^{21}$ The history of bayonet training offers a particularly pertinent example of the historical connections between dance choreography and combat training. Bayonets were first introduced to the French Army in the seventeenth century by Jean Martinet, a pioneer of modern military drilling methods. The steps and movements of bayonet fighting were closely matched to those of dances in the French royal court. ${ }^{22}$

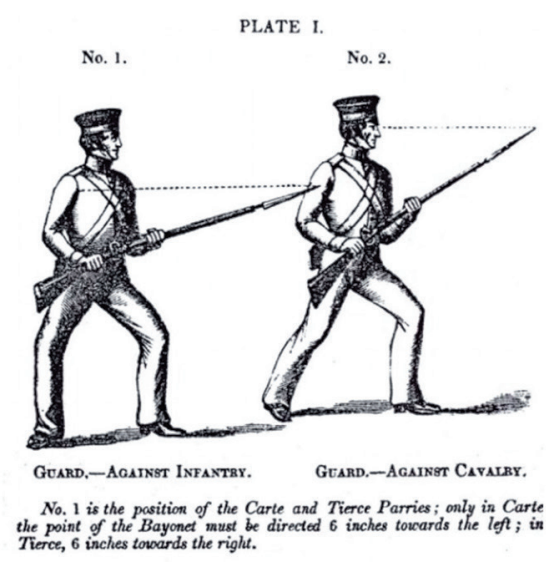

Choreography of the bayonet. ${ }^{23}$

Bayonet training was considered central to maintaining the fighting power of the British Army during World War I; for although the bayonet was already acknowledged to be obsolete

19 Michel Foucault, Discipline and Punish: The Birth of a Prison, trans. Alan Sheridan (New York: Vintage Books,1995), 138. This also accounts for the historically close relationship between combat training and athletic sports, which have often been allotted the same psycho-physiological training role. See James D. Campbell, The Army Isn't All Work: Physical Culture and the Evolution of the British Army, 1860-1920 (Burlington: Ashgate, 2012), 125 and 159-63.

20 William H. McNeill, Keeping Together in Time: Dance and Drill in Human History (Cambridge: Harvard University Press, 1997), 101.

21 Maureen Needham, "Louis XIV and the Académie Royale de Danse, 1661: A Commentary and Translation," Dance Chronicle 20.2 (1997): 180.

22 See Jessica Behm, "Bodies of War: The Embodiment of Force in Theaters of War" (PhD dissertation, Dance History and Theory, UC Riverside, 2014).

23 Richard F. Burton, A Complete System of Bayonet Exercise (London: William Clowes and Sons, 1853). See also "Bayonet History and Drill." TheFirearmBlog.com, last modified March 21, 2016, http://www. thefirearmblog.com/blog/2015/o4/16/bayonet-history-and-drill-circa-1861/. 
weaponry in the era of the machine gun, it was still considered key as a fighting technology because of its utility in psycho-physiological discipline. ${ }^{24}$ In American military training, the bayonet drill was likewise used as a psycho-physiological training method throughout the twentieth century - after which it was replaced by training in fighting with knives in hand-tohand combat. ${ }^{25}$

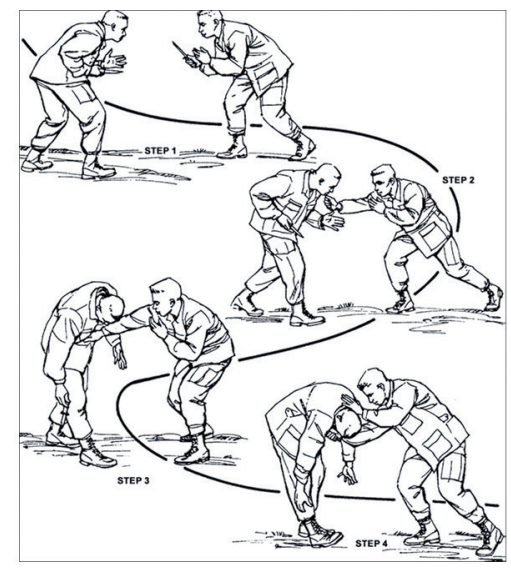

Choreography of knife fighting from the U. S. Army Field Manual. ${ }^{26}$

In West Side Story, choreography is also represented as necessary to inculcate the proper fighting affect, which is named "cool." As an affective strategy, cool emphasizes selfcontainment - not a full repression of emotion, but a calibrated self-control that is energized by emotions roiling just below the surface. In her book Digging the Africanist Presence in American Performance, Brenda Dixon Gottschild defines cool as "an attitude (in the sense that African Americans use that word) that combines composure with vitality": the self-control of one "whose body and energy may be working fast, hard, and hot, but whose face remains cool." 27 Riff, as the leader of the Jets, does more than any other character to regulate the level of violence between the two gangs while insisting on its necessity. Following his accidental death in the rumble, the task of making sure that the Jets keep their cool is passed to the character aptly named Ice. His abilities in this regard secure his position as the gang's next leader. And this passing of the mantle is effected in the dance number following the rumble, named "Cool."

In the scene immediately preceding this dance, the Jets are shown succumbing to a range of emotional reactions over Riff's death. The girls are crying, and Action and A-Rab start fighting with each other over whether there is a need to take further revenge against the Sharks.

24 Campbell, The Army Isn't All Work, 167.

25 Jeff Schogol, "Has the Army Eliminated Bayonet Training?" Stars and Stripes, accessed March 11, 2011, http://www.stripes.com/blogs/the-rumor-doctor/the-rumor-doctor-1.104348/has-the-armyeliminated-bayonet-training-1.137356.

26 United States Army, Field Manual No. 3-25.150. Combatives (Washington, DC: Department of the Army, 2002), 7-25, accessed May 15, 2012, http://sill-www.army.mil/428thfa/FM\%2O3-25.150\%2O (Combatives).pdf.

27 Brenda Dixon Gottschild, Digging the Africanist Presence in American Performance (Westport, CT: Greenwood Press, 1996), 16. 


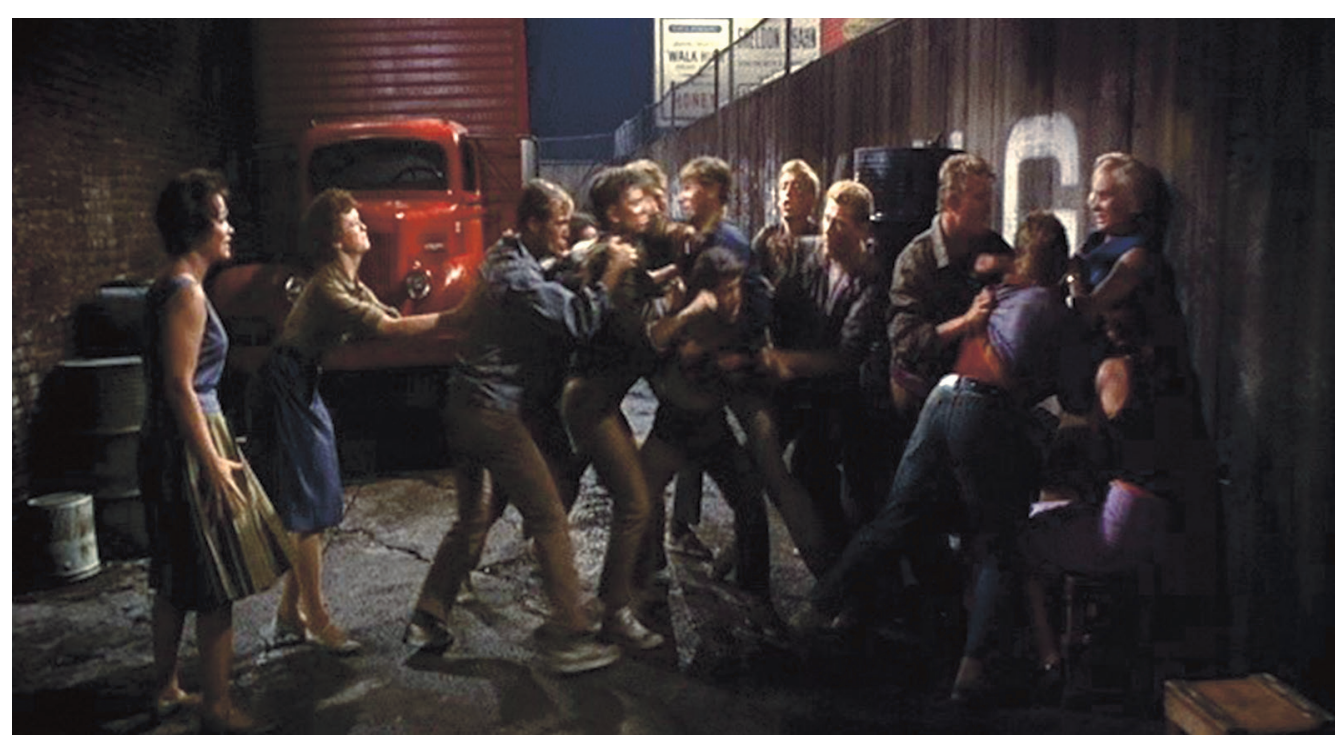

The Jets get hot and fight amongst themselves

It is shown that these uncontrolled emotions are a form of self-betrayal that makes the Jets vulnerable to outside attack. A man leans out of a window above them and throws a bottle that shatters at their feet. "Shut up down there you dirty lousy good for nothin's!" he yells. Action yells back at him and picks up a rock, but Ice herds everyone into an enclosed parking garage, where they receive affective disciplining in how to be cool. He admonishes the group, "No matter who or what is eatin' at you, you show it, buddy boys, and you are dead! You are cuttin' a hole in yourselves for them to stick in a red-hot umbrella and open it [...] wide! [...] You wanna live in this lousy world? Play it cool!"28

However, because cool is an embodied affective strategy, the Jets cannot simply decide mentally to exhibit it. They must actually dance their way into it, engaging affective discipline as a psycho-physiological process. To this end, Ice's metronomic finger snapping gives them a shared rhythm and a physical point of return. ${ }^{29}$ As a bodily event, finger snapping is grounded in a muscular tension building beneath the surface, a tension that is revealed only when it is released as sound. That is why it makes an apt physical synecdoche of coolness, which is an attitude of controlled tension. In an effort to establish among the Jets the physical and emotional tenor of cool, Ice leads them into a session of finger snapping. He walks through the group making eye contact with the heated Jets, getting them to engage both psychologically and physically in his cool practice. The consistent rhythm of their finger snapping re-establishes a group dynamic and also begins to relax the tempo of the Jets' overheated emoting.

In order for cool to be established, however, the body as a whole must be engaged and disciplined, and the dance's choreographic structure dramatizes the necessarily slow progress of this drill. Early in the dance, as they work to "get cool," four Jets forcefully punch their right arms upward. But they are censured by the Jet girls, who respond with a "Shhhhhhhh,"

28 Ernest Lehman, West Side Story: Screenplay (Beverly Hills: MGM Home Entertainment, 2003), 92-93.

29 On the significance of rhythm in the aesthetic of cool, see Daniel Belgrad, The Culture of Spontaneity (Chicago: University of Chicago Press, 1998), 191-93; or Daniel Belgrad, Kultura spontannosti [The Culture of Spontaneity], trans. Yuliya Kazanova (Kyiv: Fakt, 2008), 271-74. 


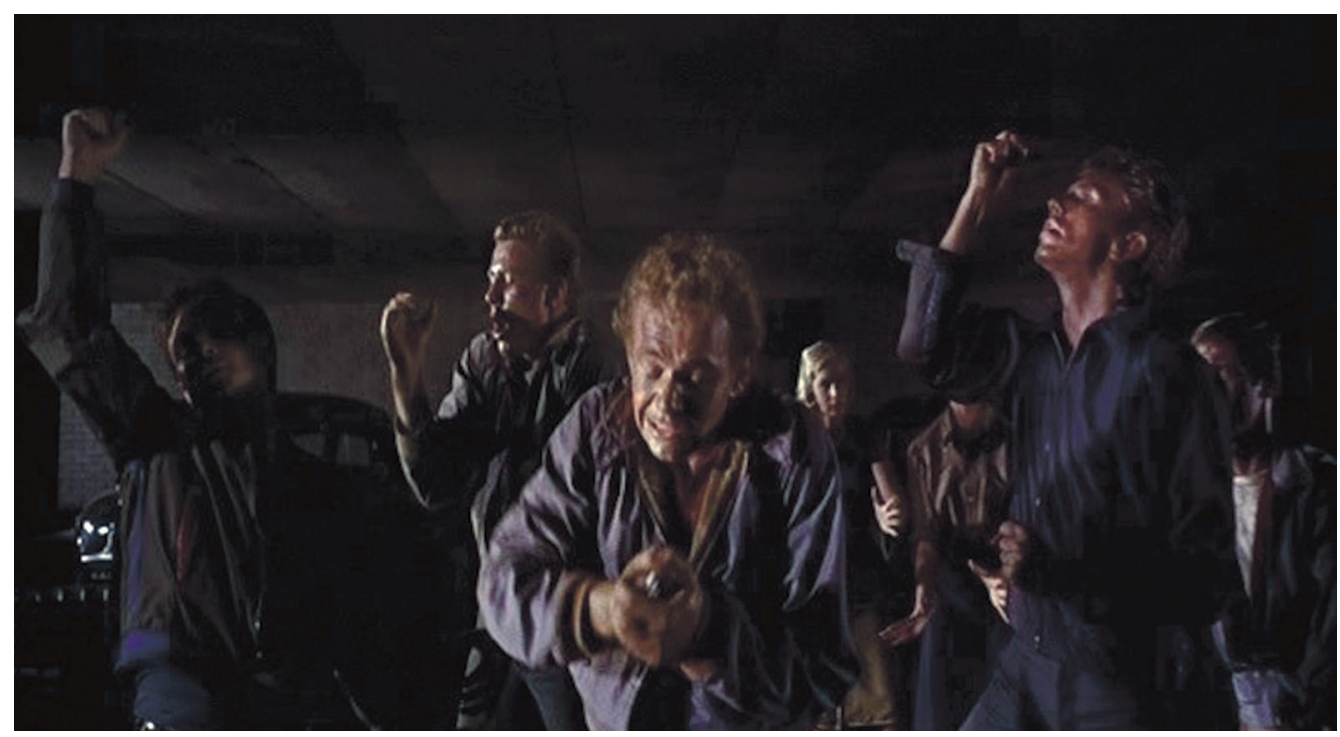

A-Rab struggles for self-control

attempting to quiet the boys' outburst. The four Jets then lower their outstretched arms with effort, shaping clenched fists to expel their uncontrollable emotions. Only A-Rab remains out of control, and his clenched fist repeatedly and painfully punches his own left hand, until a verbal admonishment from Ice serves to reinforce the claims of coolness, at which point A-Rab's tight, curled-up fingers become loose, flexible, and mobile. He begins to cool down, and this affect spreads through his body as he glides from side to side, dancing out light, intricate footwork. Then, suddenly and unexpectedly, he relapses into his former hot demeanor, punching his arm out to the side as he makes his fingers into the shape of a gun and screaming, "Pow!" while laughing hysterically.

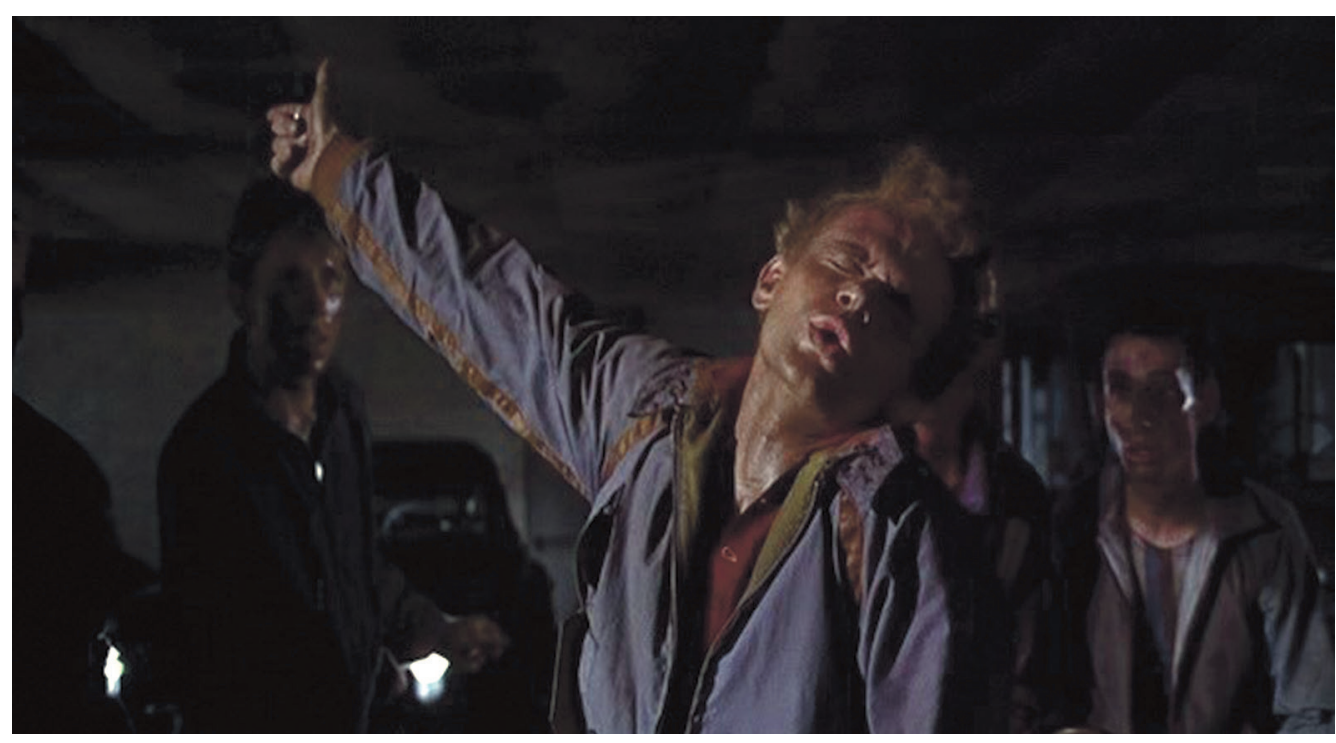

A-Rab overcome by violent emotion

Over the course of the dance, A-Rab's uncontrollable violent gesture will not be fully eliminated, but rather disciplined and integrated into the choreography, so that its violence can 
be redirected at the appropriate target. As Brenda Dixon Gottschild has explained, the heat of emotion is always present beneath the surface of cool: "A laugh, a grimace, a verbal expression that seems to come out of nowhere to break, intercept, or punctuate the established mood by momentarily displaying its opposite and, thus, mediating a balance." ${ }^{30}$ Subsurface emotions are represented for example in the intensity of Ice's facial expression, which reveals the tension resulting from his struggle to hold his emotions in check. As the dance progresses, individual Jets reach towards the garage ceiling, hurling themselves into the air, transferring their energy overhead by flinging their arms and legs high and shouting "Pow!" But each of these breaks from the dancing ensemble is short-lived, and the dancers finally join in a unison rendition of "Pow!" followed by a jumping turn which slides them onto the floor on their sides. Then the last phase of the dance demonstrates their accomplishment of cool, by presenting an extended period in which they display their capacity to dance and even sing in unison. ${ }^{31}$

Only when everyone has gotten cool, as evidenced by their ability to do this, does Ice lead the Jets back out of the parking garage and onto the street. Action then goes gunning for the man who threw the bottle, but this time with the full backing of the unified Jets gang. He points his finger coolly at the camera (which offers us a point-of-view shot from the man's window) and mimes shooting him, reiterating "Pow!" Action's final "Pow!" demonstrates the affective distance that the Jets have travelled since A-Rab’s original outburst, and the power of affective restraint in conjunction with confrontation.

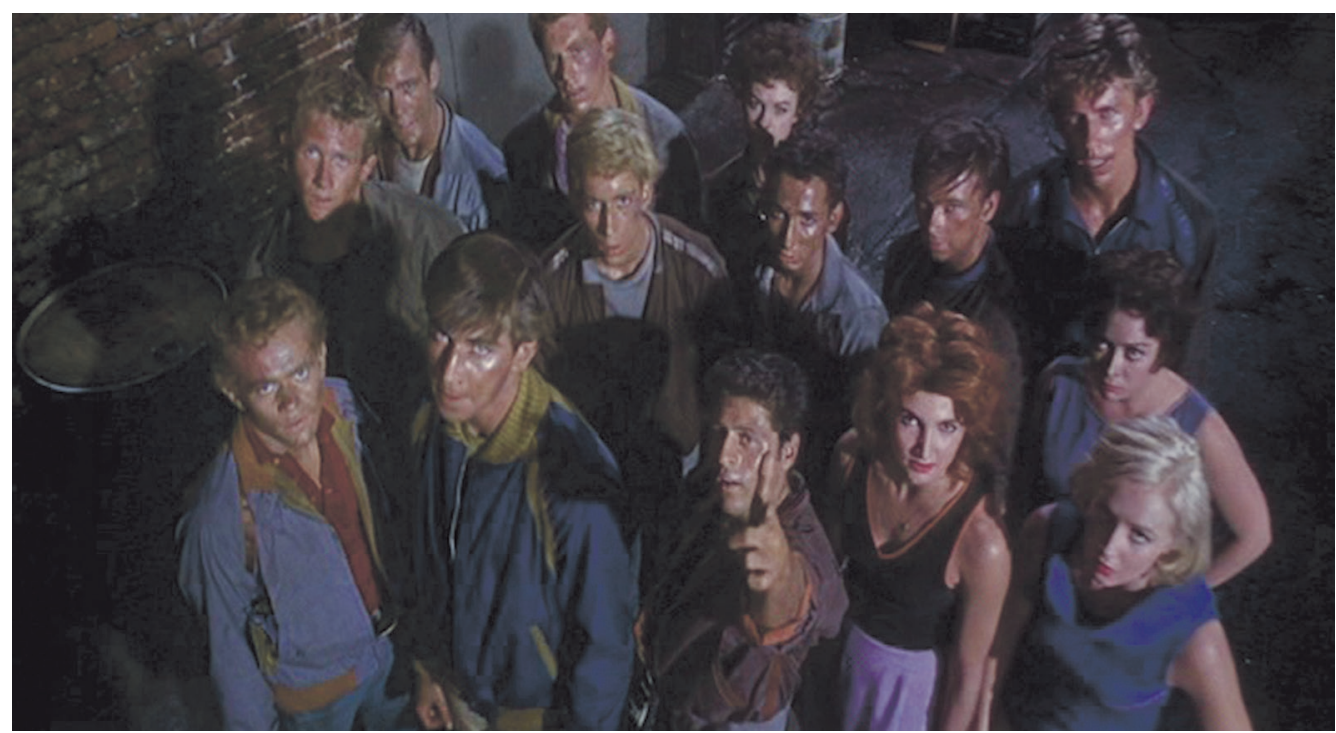

The Jets fight coolly. Pow!

30 Gottschild, Digging the Africanist Presence, 16-17.

31 For intriguing 21st-century equivalents, see the phenomenon of "combat dancing" among American soldiers in Afghanistan and Iraq, in which troops in battle regalia, carrying deadly weapons and surrounded by other materiel of war, record videos of themselves performing intricate ensemble dancing and then post them to social media sites like YouTube. For example, "The Cupid Shuffle Army Edition," last modified March 1, 2011, https://www.youtube.com/watch?v=lbDHvt1jEYo; and "Just Dance Remake US Troops style Lady Gaga," last modified October 3, 20o9, https://www.youtube. com/watch?v=02DJCX4kcAY. 


\section{The "Diplomacy of Violence"}

With the knowledge gained from our analyses of these dances, we can approach the political rhetoric of the Cold War era with a new vocabulary of analytical concepts. We are rewarded with new insights into the cultural basis of American Cold War diplomacy. This was founded on a compound of two potentially antithetical principles: confrontation and restraint.

Espousing an attitude of "political realism," Cold War politicians and intellectuals alike stressed the need for a healthy degree of skepticism in navigating international power relations. ${ }^{32}$ To trust in the good faith of other powers was considered dangerously naive or, in the popular lingo of the time, "soft." 33 After President Franklin D. Roosevelt's death, Republicans accused Harry S. Truman's administration of being "soft on communism." ${ }^{4}$ The most frequently referenced historical example of such softness was the "appeasement" of Hitler in 1938. Beginning with the Yalta conference in 1945, Americans worried publicly about the dangers of "appeasing" Stalin. ${ }^{35}$ John Russell Deane, a Major General in the U. S. Army who had served at the U. S. Embassy in Moscow during the war, warned in his 1947 book Strange Alliance (portions of which were published in Henry Luce's influential Life magazine) that during the war "American generosity was taken as a sign of weakness, and the Soviet leaders became increasingly overbearing and demanding... We continued our appeasement policy long after it was necessary to do so." By contrast, he continued, "whenever we did take a firm stand during the war, our relations took a turn for the better." ${ }^{36}$ Therefore, he concluded, a strategy of confrontation in relation to Soviet policy was necessary:

We should be fully prepared to meet force with force. [...] The [Soviet] program is doomed to failure unless the democracies completely close their eyes to its danger and facilitate its fulfillment through appeasement or apathetic indifference. ${ }^{37}$

What Deane termed "indifference" was another affective complex of cultural concern, which was qualitatively different from that of appeasement. While appeasement was emotionally "soft," indifference was marked as excessive emotional detachment, resulting in an incapacity to respond appropriately due to too little connection between mind and emotion. Many social critics, including sociologist C. Wright Mills, worried that mass entertainments

See Joel Rosenthal, Righteous Realists: Political Realism, Responsible Power, and American Culture in the Nuclear Age (Baton Rouge: Louisiana State University Press, 1991), 8 and 123. Kyle A. Cuordileone, Manhood and American Political Culture in the Cold War (New York: Routledge, 2005), 13 and 24-25. Cuordileone, Manhood and American Political Culture, 38-39. See Les K. Adler and Thomas G. Paterson, "Red Fascism: The Merger of Nazi Germany and Soviet Russia in the American Image of Totalitarianism, 1930's-1950's," American Historical Review 75.4 (1970): $1057-58$. John R. Deane, The Strange Alliance: The Story of Our Efforts at Wartime Co-operation with Russia (New York: Viking Press, 1947), 297. 
were fouling the necessary connections between thinking and feeling, leaving people incapable of making sensible decisions. In his essay "The Structure of Power in American Society," from 1958, Mills polemicized that:

The demise of the public must be seen in connection with the rise of centralized organizations, with all their new means of power, including those of the mass media of distraction. These, we now know, often seem to expropriate the rationality and the will of the terrorized or - as the case may be - the voluntarily indifferent society of masses. [...] They lose their will for decision because they do not possess the instruments for decision. ${ }^{38}$

In its extreme, indifference was imagined to turn humans into virtual automatons, as in Mills's condemnation of television viewers as "cheerful robots," or in the popular science-fiction film Invasion of the Body Snatchers from 1956, in which emotionless aliens inhabit human bodies. The "brainwashed" Communist "puppet" in the 1962 film The Manchurian Candidate is an affectless assassin in a hypnotic trance. Its danger also registered in popular fears of a nuclear holocaust that would be unleashed mechanistically through "the push of a button." 39 Social psychologist Erich Fromm, in his 1955 book The Sane Society, condemned what he called a "schizophrenic indifference" to the threat of nuclear war - a phrase encapsulating the element of psychological dissociation with which this emotional detachment was associated. ${ }^{40}$

Most importantly, the distinction between emotionally disciplined violence, marked as legitimate, and emotionally undisciplined violence, marked as pathological, emerges as an essential feature of American Cold War diplomacy. As political theorist Michael Rogin details, emotional self-restraint has historically stood as a core value in American political culture: liberal political ideology valorizes self-control as the necessary basis of personal independence, and of a social order founded on individual freedoms and contractual obligations. ${ }^{41}$ Thus affective discipline is enshrined in the mythification of the American frontier experience as a confrontation between the "civilized" and the "wild," in which the Native American is constructed as a "savage" other. ${ }^{42}$ Nineteenth-century observers described the Native Americans as lacking the "principles of restraint" necessary to American civilization. ${ }^{43}$

Horatio Greenough's sculpture The Rescue, which stood on the steps of the U. S. Capitol from 1853 until 1958, testifies to the centrality of this myth in American national identity. In Greenough's monument, Civilization (in classical garb) combats the nearly naked Savage, preventing him from harming innocents (the cowering woman and baby). This is accomplished

38 C. Wright Mills, Power, Politics, and People (New York: Oxford University Press, 1963), 37.

39 Thomas Hine, Populuxe (New York: Knopf, 1986), 133-35.

40 See Erich Fromm, Sane Society (New York: Henry Holt and Co., 1955), 12-17; and Robert A. Divine, Blowing on the Wind: The Nuclear Test Ban Debate (New York: Oxford University Press, 1978), 166.

41 Michael Rogin, Ronald Reagan: The Movie, and Other Episodes in Political Demonology (Berkeley: University of California Press, 1988), 135.

42 Rogin, Ronald Reagan, 161.

43 Lewis Cass, "Annual Report of the Secretary of War for 1831," quoted in Rogin, Ronald Reagan, 142. 
not by harming the savage but by restraining him. The civilized rescuer stares meaningfully into the savage's face, for the "rescue" that is being effected is also meant to be his. Through their bodily interaction, Greenough represents a process of subject formation through a coerced affective discipline. Nineteenth-century political leaders similarly expressed the conviction that "coercive discipline" 44 was necessary to inculcate restraint in the savage, who would otherwise exhibit a "violent loss of self-control." 45

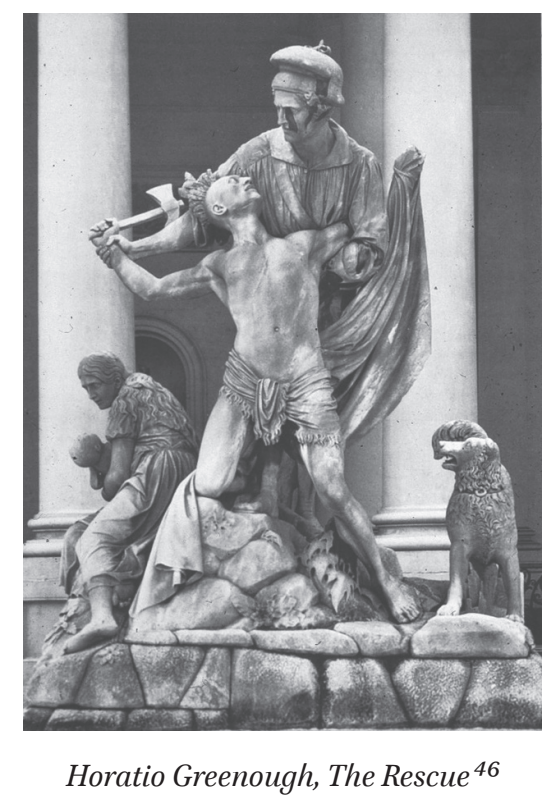

This ideological structure was urgently re-energized in the Cold War context via the specter of "totalitarianism." As an intellectual construction, totalitarianism merged the images of Nazism and Stalinism ${ }^{47}$ to form the new face of savagery. In a 1953 conference on the topic organized by Harvard political theorist Carl Friedrich for the American Academy of Arts and Sciences, social psychologist Erik Erikson offered a psychoanalytic analysis of totalitarianism that makes this connection clear. Erikson contrasted "wholeness" with "totality," and described the former as built on a foundation of trust, while he associated the latter with an "unmanageable" rage. ${ }^{48}$ Erikson's description of "wholeness" as an accomplishment of the mature personality duplicates the image of liberal political ideology as described by Rogin, in which self-restraint is defined as the necessary premise of the social contract. According to Erikson, "wholeness" is founded on a self-trust rooted in dependability: "For only when thoroughly dependable [...] can he become independent [...] [through] a slow developmental process which leads from extreme helplessness to a high sense of freedom." 49 By contrast, in "totality" the impotence

44 John Forsyth in U. S. Congress, Register of Debates(1829-30), quoted in Rogin, Ronald Reagan, 161.

45 Rogin, Ronald Reagan, 144.

46 https://en.wikipedia.org/wiki/The_Rescue_(statue)\#/media/File: GreenoughRescue.jpg.

47 Adler and Paterson, "Red Fascism," 1046-48.

48 Erik Erikson, "Wholeness and Totality — A Psychiatric Contribution," in Totalitarianism, ed. Carl J. Friedrich (New York: Grosset and Dunlap, 1954), 169.

Erikson, "Wholeness and Totality," 156-57. 
of infantile frustrations leads to "an experience of 'total' rage, with fantasies of [...] total domination." ${ }^{0}$ The result is an excessive "righteousness" that makes the individual susceptible to totalitarian indoctrination. ${ }^{51}$ Thus, as in Greenough's sculpture, the absence of self-control will lead necessarily to others' controlling you.

The challenge of totalitarianism, Americans were determined, would be met by a new round of "coercive discipline" directed at the Soviet savage. The realpolitik outlook of influential Cold War political thinker and Presidential advisor Henry Kissinger ${ }^{52}$ reproduced the cultural logic of Erikson's argument. Kissinger wrote in 1954 that "the achievement of self-restraint is the ultimate challenge of the social order." He harbored the same distrust of "righteous rage" that Erikson associated with the totalitarian personality, arguing that "to restrain the exercise of righteous power" was the necessary focus of political realism. ${ }^{53}$ Political scientist Thomas Schelling, Kissinger's colleague at Harvard, renamed the new coercive discipline the "diplomacy of violence," characterized by a combination of confrontation and restraint on America's part. American "commitment" must be displayed, he wrote, in confronting the threat of Communist expansion in Formosa and Korea. ${ }^{54}$ At the same time, the existence of competing nuclear arsenals dictated a strategy of "limited war" as opposed to "total war"; since America could not hope to conquer Russia, "with nuclear weapons available, the restraint of violence [...] must occur during war itself." 55

In this context, wrote Schelling, restraint must be wielded strategically, not just acknowledged as a limitation; for "the power to hurt is most successful [as a form of influence] when it is held in reserve." As opposed to violence that is "wanton and meaningless or [...] getting out of hand [...] in the excitement and fatigue of warfare," ${ }^{56}$ Schelling argued for a diplomacy of violence that depended on the exercise of a "cool premeditated violence to persuade somebody that you mean it and may do it again." 57

This "realist" orientation of restrained confrontation was opposed, in the American political imaginary, both to "appeasement" (a term that was used to denigrate the avoidance of confrontation) and to the option of all-out nuclear attack (a scenario in which the Soviets were typically imagined as the aggressors). These were not mere theories; the affective mappings they referenced were used to plan and justify actual military action. In the Cuban missile crisis of 1962, for example, the political drama of President Kennedy's "quarantine" of Cuba played out along these lines. The very word "quarantine" chosen by Kennedy implies pathological bodies

$50 \quad$ Erikson, "Wholeness and Totality," 163.

$51 \quad$ Erikson, "Wholeness and Totality," 170.

$5^{2}$ Kissinger's published writings from this period include Nuclear Weapons and Foreign Policy (1957) and The Necessity for Choice: Prospects of American Foreign Policy (1961).

Henry Kissinger, “The Conservative Dilemma: Reflections on the Political Thought of Metternich," American Political Science Review 48 (1954): 1029-30, cited in Jeremi Suri, Henry Kissinger and the American Century (Cambridge, MA: Harvard University Press, 2007), 146. Thomas Schelling, Arms and Influence (New Haven: Yale University Press, 1966), 49-50.

Schelling, Arms and Influence, 20.

56 Schelling, Arms and Influence, 9.

57 Schelling, Arms and Influence, 1 and 3. 
and the urgency of coercively managing their spatial location and relocation - a metaphorical choreography involving battleships and missiles as props and prosthetics. In his televised address on October 22, the President invoked the cultural binary of civilized and savage, vowing to meet the "sudden," "reckless" and "provocative" acts of the Soviets with America's own "patience and restraint." He reminded his viewing public of the nation's need for "self-discipline" during the coming confrontation, "in which our patience and our will will be tested." He characterized Cuba's revolutionary leaders as lacking emotional independence, describing them as the "puppets" of Soviet "tyrants." Conversely, his characterization of the American position emphasized the virtues of trustworthiness and contractual responsibility, stating that the Soviet provocation could not be ignored if "our commitments are ever to be trusted again by either friend or foe. $[\ldots]$ This nation is [...] true to our word." On these grounds Kennedy justified his confrontational stance and eschewed softness. While acknowledging the terrifying possibility of nuclear war, he insisted that America would meet the Soviet threat with "determination" and would not "shrink" from "that risk at any time it must be faced." In this connection, he reminded his audience, "the 1930's taught us a clear lesson" that appeasement was ultimately more dangerous than confrontation. ${ }^{58}$ Speculating on the possible Soviet response to the quarantine, the President and his advisors worried about the potential for an "unmanageable escalation" 59 but, as Dean Acheson summarized, "we hope that cooler heads will prevail." 60

\section{Conclusion}

Affective strategies are a key component of the ideological processes of subject formation. Focusing on this enables a new methodology aimed at understanding the historically specific structures by which a culture maps affects and assigns them values; and beyond that, how this mapping legitimates social power. The legitimation of the exercise of force by the nation-state is one of the most important functions of ideology. In Cold War America, this was accomplished through an affective mapping denoted by the terms "soft," "indifferent," "hot," and "cool."

This affective mapping was culturally reinforced by innumerable texts and instances of lived experience. For the purposes of this essay, we have focused on how it was communicated in the film West Side Story. We chose this text in particular because it is a dance musical and, as an art form, dance is particularly focused on a bodily display of affect and the processes of affective discipline. While language can signify affective complexes such as "cool," it can do so only symbolically ${ }^{61}$ and must treat them perforce as found objects; the dancing body, on the other hand, can signify indexically both the affective complex and the very processes of its formation in the subject. This is what is displayed in the West Side Story dance "Cool," just as a

$5^{8}$ See John F. Kennedy, "Address on the Cuban Crisis October 22, 1962," in Modern History Sourcebook: Fordham University, accessed July 4, 1998, https://legacy.fordham.edu/halsall/mod/1962kennedycuba.html. of Illinois Press, 1993), 173.

60 Quoted in Winkler, Life Under a Cloud, 174.

61 See Charles Peirce, The Essential Peirce, vol. 2 (Bloomington: Indiana University Press, 1998), 53-56. 
troop of marching soldiers offers indexical signification of the affective discipline of repeated military drills.

The dances of West Side Story reproduce the cultural logic legitimating Cold War militarism. The affective disposition that is valorized is confrontational, not soft; committed, not detached; and not emotionally excessive, but cool. The pivotal fight scene constructs unregulated violence as the only alternative to regulated violence. Pacifism is rejected as inviting victimization. We are also shown how choreographed violence is disciplined (cool) violence, and thus regulated and limited in scope and capable of being harnessed to a rational purpose. By contrast, the failure of cool is marked by the kind of unregulated violence that we are shown at the end of the rumble: the indiscriminate violence of a Hobbesian war of all against all, like the specter of an atomic destruction unleashed on an unsuspecting population of non-combatants. Face up and keep cool must be said to be the real moral lesson of this musical - one shared by America's Cold War political thinkers like Schelling and Kissinger, Erikson and Deane, Acheson and Kennedy. What is often taken to be its moral lesson - the evils of racial prejudice - functions only as a context for demonstrating this important ideological principle.

\section{Bibliography}

Adler, Les, and Thomas Paterson. "Red Fascism: The Merger of Nazi Germany and Soviet Russia in the American Image of Totalitarianism, 1930's-1950's." American Historical Review 75.4 (1970): 1046-64.

Altieri, Charles. The Particulars of Rapture: An Aesthetics of the Affects. Ithaca: Cornell University Press, 2003.

Behm, Jessica. "Bodies of War: The Embodiment of Force in Theaters of War." PhD dissertation, Dance History and Theory, UC Riverside, 2014.

Belgrad, Daniel. "Square Ring." Intellectual History Newsletter 23 (2001): 24-34.

Belgrad, Daniel. The Culture of Spontaneity. Chicago: University of Chicago Press, 1998.

Boring, Edwin et al. Psychology for the Fighting Man. Washington: Infantry Journal, Penguin Books, 1943.

Burton, Richard F. A Complete System of Bayonet Exercise. London: William Clowes and Sons, 1853. Accessed November 27, 2015. http://burtoniana.org/books/1853-A\%2oComplete\%2O System\%2oof\%2oBayonet\%2oExercise/burton-1853-bayonet.pdf.

Campbell, James D. The Army Isn't All Work: Physical Culture and the Evolution of the British Army, 1860-1920. Burlington: Ashgate, 2012.

Cohen, R. Robert. "Factors in Adjustment to Army Life: A Plan for Preventive Psychiatry by Mass Psychotherapy," War Medicine 5 (February 1944): 83-94.

Cuordileone, Kyle. Manhood and American Political Culture in the Cold War. New York: Routledge, 2005 .

Deane, John R. The Strange Alliance: The Story of Our Efforts at Wartime Co-operation with Russia. New York: Viking Press, 1947.

DefensiveCarry.com. "How Helpful is Being Angry when in a Fight?" Last modified November 23 , 2011. http://www.defensivecarry.com/forum/carry-defensive-scenarios/131675-howhelpful-being-angry-when-fight.html. 
Desmond, Jane. "Embodying Difference: Issues in Dance and Cultural Studies." Cultural Critique 26 (1993-1994): 33-63.

Divine, Robert A. Blowing on the Wind: The Nuclear Test Ban Debate. New York: Oxford UP, 1978.

Dodds, Sherril. Dancing on the Canon: Embodiments of Value in Popular Dance. New York: Palgrave Macmillan, 2011.

Erikson, Erik. "Wholeness and Totality — A Psychiatric Contribution." In Totalitarianism, edited by Carl J. Friedrich, 156-71. New York: Grosset and Dunlap, 1954.

Foster, Susan Leigh. Reading Dancing: Bodies and Subjects in Contemporary American Dance. Berkeley: University of California Press, 1986.

Foucault, Michel. Discipline and Punish: The Birth of a Prison. Translated by Alan Sheridan. New York: Vintage Books, 1995 .

Franko, Mark. Dance as Text: Ideologies of the Baroque Body. Cambridge: University Press, 1993.

Fromm, Erich. Sane Society. New York: Henry Holt and Co., 1955.

Herman, Ellen. The Romance of American Psychology: Political Culture in the Age of Experts. Berkeley: University of California Press, 1996.

Gere, David. How to Make Dances in an Epidemic: Tracking Choreography in the Age of AIDS. Madison: University of Wisconsin Press, 2004.

Gottschild, Brenda Dixon. Digging the Africanist Presence in American Performance. Westport, CT: Greenwood Press, 1996.

Hine, Thomas. Populuxe. New York: Knopf, 1986.

Jameson, Fredric. The Political Unconscious: Narrative as a Socially Symbolic Act. Ithaca: Cornell University Press, 1982.

Kennedy, John F. "Address on the Cuban Crisis October 22, 1962." Modern History Sourcebook: Fordham University. Accessed July 4, 1998. https://legacy.fordham.edu/halsall/ $\mathrm{mod} / 1962 k e n n e d y-c u b a \cdot h t m l$.

Lears, Jackson T. J. “The Concept of Cultural Hegemony." American Historical Review 90.3 (1985): 568-93.

Lehman, Ernest. West Side Story: Screenplay. Beverly Hills: MGM Home Entertainment, 2003.

Manning, Susan. Ecstasy and the Demon: Feminism and Nationalism in the Dances of Mary Wigman. Berkeley: University of California Press, 1993.

McCormack, Derek. Refrains for Moving Bodies: Experience and Experiment in Affective Spaces. Durham: Duke University Press, 2014.

McNeill, William H. Keeping Together in Time: Dance and Drill in Human History. Cambridge: Harvard University Press, 1997.

Mills, C. Wright. Power, Politics, and People. New York: Oxford University Press, 1963.

Needham, Maureen. "Louis XIV and the Académie Royale de Danse, 1661: A Commentary and Translation." Dance Chronicle 20.2 (1997): 173-90.

Negrón-Muntaner, Frances. "Feeling Pretty: West Side Story and Puerto Rican Identity Discourses." Social Text 18.2 (2000): 83-106.

Peirce, Charles. The Essential Peirce. Volume 2. Bloomington: Indiana University Press, 1998.

Rogin, Michael. Ronald Reagan: The Movie, and Other Episodes in Political Demonology. Berkeley: University of California Press, 1988.

Rosenthal, Joel. Righteous Realists: Political Realism, Responsible Power, and American Culture in the Nuclear Age. Baton Rouge: Louisiana State University Press, 1991. 
Sandoval-Sanchez, Alberto. José Can You See: Latinos On and Off Broadway. Madison: University of Wisconsin Press, 1993.

Schelling, Thomas. Arms and Influence. New Haven: Yale University Press, 1966.

Schogol, Jeff. "Has the Army Eliminated Bayonet Training?" Stars and Stripes. Accessed November 27, 2015. http://www.stripes.com/blogs/the-rumor-doctor/the-rumor-doctor-1.104348/hasthe-army-eliminated-bayonet-training-1.137356.

Spivak, Gayatri. “Can the Subaltern Speak?" In Marxism and the Interpretation of Culture, edited by Cary Nelson and Lawrence Grossberg, 271-313. Basingstoke: Macmillan Education, 1988.

Suri, Jeremi. Henry Kissinger and the American Century. Cambridge, MA: Harvard University Press, 2007.

TheFirearmBlog.com. "Bayonet History and Drill, Circa 1861." Last modified April 16, 2015. http:// www.thefirearmblog.com/blog/2015/o4/16/bayonet-history-and-drill-circa-1861/.

Tomkins, Silvan. Exploring Affect: The Selected Writings of Silvan S. Tomkins, edited by E. Virginia Demos. New York: Cambridge University Press, 1995.

United States Army. Combatives: Field Manual No. 3-25.150. Washington, DC: Department of the Army, 2002. Accessed November 27, 2015. http://sill-www.army.mil/428thfa/FM\%20 3-25.150\%20(Combatives).pdf.

West Side Story. DVD. Directed by Jerome Robbins and Robert Wise. 1961; Beverly Hills, CA: MGM Home Entertainment, 1998.

Williams, Raymond. The Long Revolution. New York: Columbia University Press, 1961.

Winkler, Allan. Life Under a Cloud: American Anxiety about the Atom. Urbana-Champaign: University of Illinois Press, 1993.

YouTube. "The Cupid Shuffle - Army Edition." Last modified March 1, 2011. https://www. youtube.com/watch?v=lbDHvtijEYo.

YouTube. "Just Dance Remake US Troops style Lady Gaga." Last modified October 3, 2009. https://www.youtube.com/watch?v=02DJCX4kcAY.

\section{(7)}

Daniel Belgrad is an Associate Professor in the Department of Humanities and Cultural Studies at the University of South Florida. His research interests lie at the intersection of intellectual history and popular culture studies. He is currently at work on a book investigating the impact of ecological thinking on American culture during the 1970s. He was a senior Fulbright Scholar to Ukraine in 2006-2007. He is the author of Vid teorii do metodiv [From Theory to Method] (Kyiv: NaUKMA Press, 2010) and of Kultura spontannosti [The Culture of Spontaneity]. Translated by Yuliya Kazanova (Kyiv: Fakt, 2008).

Ying Zhu is an Assistant Professor of Dance in the School of Theatre and Dance and an Affiliate Assistant Professor in the Department of Humanities and Cultural Studies at the University of South Florida. Her research interests converge at the intersection of bodies, space, architecture, and memory. At present, she is at work on a book manuscript using the Vietnam Veterans Memorial in Washington, D.C. as case study to consider the body as a complicating factor in processes of national, collective memorialization. 